ZOOLOGIA 29 (4): 308-317, August, 2012

doi: $10.1590 /$ S1984-46702012000400004

\title{
Species of Drosophila (Diptera: Drosophilidae) attracted to dung and carrion baited pitfall traps in the Uruguayan Eastern Serranías
}

\author{
Beatriz Goñi ${ }^{1,4}$, Mónica Remedios², Patricia González-Vainer², María Martínez² \& Carlos R. Vilela \\ ' Sección Genética Evolutiva, Departamento de Biología Animal, Instituto de Biología, Facultad de Ciencias, Universidad de la \\ República. Iguá 4225, 11400 Montevideo, Uruguay. \\ 2 Sección Entomología, Departamento de Biología Animal, Instituto de Biología, Facultad de Ciencias, Universidad de la \\ República. Iguá 4225, 11400 Montevideo, Uruguay. \\ ${ }^{3}$ Departamento de Genética e Biologia Evolutiva, Instituto de Biociências, Universidade de São Paulo. Rua do Matão, \\ Travessa 14, 321, 05508-090 São Paulo, SP, Brazil. \\ ${ }^{4}$ Corresponding author. E-mail: bgoni@fcien.edu.uy
}

\begin{abstract}
This study investigates the species richness and abundance of Drosophila Fallén, 1823 attracted to dung and carrion baited pitfall traps in natural areas with heterogeneous habitats at the Sierra de Minas, Eastern Serranías, southeastern Uruguay. Collecting was carried out on a monthly basis (May 2002 through April 2003). Drosophilids accounted for $0.84 \%(n=131)$ and $3.61 \%(n=158)$ of the Diptera collected from dung $(n=15,630)$ and carrion $(n=4,382)$ pitfall traps, respectively. A total of 12 species were identified, 11 of which belong to the subgenus Drosophila (the richest) and one to the subgenus Sophophora Sturtevant, 1939. Over $90 \%$ of the Drosophila specimens collected belong to five species of the subgenus Drosophila, namely D. gaucha Jaeger \& Salzano, 1953, D. immigrans Sturtevant, $1921, D$. mediovittata Frota-Pessoa, 1954, D. aff. nappae Vilela, Valente \& Basso-da-Silva, 2004, and D. ornatifrons Duda, 1927. Drosophila cardini Sturtevant, 1916 is recorded for the first time from Uruguay. Drosophila abundance and species richness in the four habitats sampled in the Uruguayan Eastern Serranías, namely woodlands sierra, riparian forest, pine plantation and grazing grassland, were considered to be a function of habitat conservation. Diversity indices were low in all habitats. Different habitats supported particular coprophilous and necrophilous Drosophila species. The woodland sierra represents the most preserved habitat, and contributed with the highest species richness observed. Drosophila ornatifrons was the dominant species, with a restricted habitat distribution. On the other hand, grazed grassland, an environment modified by livestock management, had the lowest species richness: only a few specimens of $D$. repleta Wollaston, 1858. Regarding species composition, significant differences were found in some pairwise comparisons of groups of Drosophila species that included D. ornatifrons. Fly attraction to dung can be exploited as an alternative and/ or complementary collecting method in ecological studies of Drosophila assemblages in natural areas.
\end{abstract}

KEY WORDS. Biodiversity; coprophilous; Drosophilinae; necrophilous; Neotropical Region.

Conventional dung and carrion traps, known as baited pitfall traps, have been occasionally used to collect insects, especially beetles, for ecological studies. In general, Hymenoptera and Diptera are attracted to these traps. Ecological studies on the necrophilous entomofauna in tropical and subtropical forests and plantations in the Mexican transition zone by Morón \& Terrón $(1982,1984)$, Morón \& López-Mendéz (1985), Morón et al. (1986) and Deloya et al. (1987) showed that Diptera and Hymenoptera (Formicidae), together with Coleoptera, are the dominant insect orders, both in diversity and abundance, and that they are sensitive to habitat disturbances. Low representation of drosophilids was observed among Diptera samples in Otongo and Tlanchinol (Hidalgo, Mexico) during 1981 (MoróN \& TERRón 1984): specimens were recorded in areas of very dis- turbed tropical forest, $2.80 \%(\mathrm{n}=727$ in 25,995 collected Diptera) and $0.66 \%(\mathrm{n}=94$ in 14,185$)$ at 650 and $1,120 \mathrm{~m}$ altitude respectively, and at a slightly disturbed area of a montane forest at $1,550 \mathrm{~m}$ altitude, $1.57 \%(\mathrm{n}=39$ in 2,481). MoRóN \& López-Mendéz (1985) reported that Drosophilidae were the second most abundant flies, $38.31 \%(\mathrm{n}=1,706$ in 4,453 adult Diptera), after Phoridae $(46.58 \%, \mathrm{n}=2,074)$, amongst the necrophilous entomofauna collected in a coffee-cacao plantation, located at $430 \mathrm{~m}$ altitude on the slopes of Tacaná volcano, finca San José de La Victoria, Chiápas, Mexico. Drosophilids were also sampled $[1.57 \%(\mathrm{n}=23$ in 1,461 Diptera)] at the tropical rain forest of the Northern area of the "Sian Ka'an" Biosphere Reserve, Quintana Roo, Mexico, located at $10 \mathrm{~m}$ altitude, during 1984-1985 (Morón et al. 1986). Additional reports have 
indicated that Drosophilidae were identified among necrophilous insects sampled from the Mexican regions of Jojutla (DeloyA et al. 1987) and Tamaulipas (SÁnchez-RAmos et al. 1993). In these studies, squid or marine fish meat were used as baits in pitfall traps. Those were replaced biweekly or monthly and 95 parts of ethanol $70^{\circ}$ and 5 parts of glacial acetic acid (MORÓN \& TERRóN 1984) or commercial antifreeze liquid (SÁnchez-RAmos et al. 1993) were used as preservative solutions. As stated by MORÓN \& TERRón (1984), the preservative solutions they used do not mask the fetid volatile odors from bait, but instead enhance the attractiveness of the bait to other saprophagous insects (as Drosophilidae).

At southern latitudes, Remedios et al. (2012) reported flies of Drosophilidae among Diptera sampled in pitfall traps in natural areas at the Sierras de Minas, Department of Lavalleja, Uruguay.

Since the samples in the research papers cited above have not been identified to species, the efficacy of pitfall traps as an alternative collecting method for Drosophilidae diversity and ecological studies remains to be assayed.

Mid-latitude South American lowlands gain particular importance when the ecological patterns for faunal groups are examined. Besides some ecological and distributional considerations on Drosophila species, mostly from collecting at south and southeast Uruguay, reported by GoÑ et al. (1997, 1998), drosophilid diversity in the natural areas locally known as sierras or cuchillas is almost unknown. The most extensive sierras in Uruguay, known as the Serranías del Este (Eastern Serranías), cover a half moon - shaped area at southeastern Uruguay (Fig. 1 , forward-slashed area at right). They have a rugged topography, with altitudes ranging from 200 to $500 \mathrm{~m}$, where the key element is the unevenness between peaks and foothills, and the steep slopes. The geological basement of the Eastern Serranías System is varied and complex, especially in the southern area. Different geological formations (interspersed granitoid and last postectonic granitoids, basaltic lavas, limestone, and Pliocenic sandstones and Pleistocenic loess) are found within very short distances. This geological diversity is reflected into a variety of soil types (from the dominant shallow soils to moderately and very deep ones) associated with rocky and stony outcrops. The average annual temperature is $17^{\circ} \mathrm{C}$, with an annual rainfall between $1,000 \mathrm{~mm}$ and $1,200 \mathrm{~mm}$ (Evia \& GUDYNAS 2000). The typical sierra landscape consists of fault ridges with a regular range of hills and streams interspersed between them, and covered predominantly by patches of woody and shrubby vegetation and rocky outcrops. The Sierra de las Animas is located at the southernmost point of the Eastern Serranías, and the Sierra de Minas to the west, whereas nearby the Serranías de Sauce, Cabral and Caracoles are formed. These sierras present a major south-north axis, separated by valleys of several streams. This region is ecologically very significant, because of the wide extent of natural areas that harbor a rich fauna and flora, and has suffered little human impact. More- over, soils of the sierras are in general suitable for forestry-related activities, in particular pine and eucalyptus plantations, which have been implemented in the last 20 years in areas traditionally occupied by grasslands (Evia \& GUDYNAS 2000). Considering the mosaic distribution of the typical diverse natural ecosystems of the sierras, such as woodlands and shrub lands, grasslands, rocky and riparian forests, and the rich fauna and flora, the sierras are of great interest to researchers and conservationists (Evia \& Gudynas 2000, Brazeiro et al. 2008).

The purpose of the present study was to investigate the abundance and species composition of Drosophila attracted to dung and carrion baited pitfall traps placed in natural areas of Sierra de Minas, with different grades of anthropogenic disturbance, and compare the spatial distribution of the species and their association with habitat disturbance, as part of a research project on ecological studies on Uruguayan dung and carrion beetles (GonZÁlez-Vainer \& Morelli 2008).

\section{MATERIAL AND METHODS}

Collecting was carried out monthly within an area of $10 \mathrm{~km}^{2}$ at the Sierra de Minas, Department of Lavalleja, Uruguay, from May 2002 through April 2003. The area is adjacent to Route 81, km 105-112 at the south of the Eastern Serranías system, between $34^{\circ} 30^{\prime} 59^{\prime \prime} \mathrm{S}, 55^{\circ} 20^{\prime} 07^{\prime \prime} \mathrm{W}$ and $34^{\circ} 30^{\prime} 54^{\prime \prime} \mathrm{S}$, $55^{\circ} 19^{\prime} 53^{\prime \prime W}$ (Fig. 1). This area includes Cerro Mirador at $370 \mathrm{~m}$ altitude and other unnamed lower elevations, whose eastern side gently slopes down to the Mataojo creek. It is characterized by silt loam uliginous soil, with altitude varying from 110 to $230 \mathrm{~m}$ (GonZÁlez-Vainer \& Morelli 2008). Four areas, representing different habitats, were selected for sampling (Fig. 2): Woodlands sierra (WS). It is a natural area formed by woody and shrubby vegetation on the slopes of the hills. It has a dense vegetation of xerophytic stunted and gnarled shrubs and trees, ca 1-3 m tall, with closed canopy, ferns, and associated epiphytes. Plant species include Aloysia gratissima (Gillies \& Hook. ex Hook.) Tronc. (Verbenaceae), Azara uruguayensis (Speg.) Sleumer (Salicaceae), Colletia paradoxa (Spreng.) Escal. (Rhamnaceae), Dodonaea viscosa Jacq. (Sapindaceae), Berberis laurina Billb. (Berberidaceae), Lithraea brasiliensis Marchand (Anacardiaceae), Myrcianthes cisplatensis (Cambess.) O. Berg (Myrtaceae), Scutia buxifolia Reissek (Rhamnaceae), Celtis spinosa Spreng. (Cannabaceae), Iodina rhombifolia Hooker \& Arnot. (Santalaceae), Blepharocalyx salicifolius (Kunth) O. Berg (Myrtaceae), Myrsine laetevirens (Mez) Arechav. (Myrsinaceae), and Myrrhinium atropurpureum Schott (Myrtaceae) (MuÑoz et al. 1993).

Riparian forest (RF). It is a natural area characterized by a 5 to $7 \mathrm{~m}$ tall dense vegetation fringe formed by shrubs and trees along the Mataojo creek. Plant species include Pouteria salicifolia (Spreng.) Radlk. (Sapotaceae), Salix humboldtiana Willd. (Salicaceae), Cephalanthus glabratus (Spreng.) K. Schum. (Rubiaceae), species of intermediate height such as 

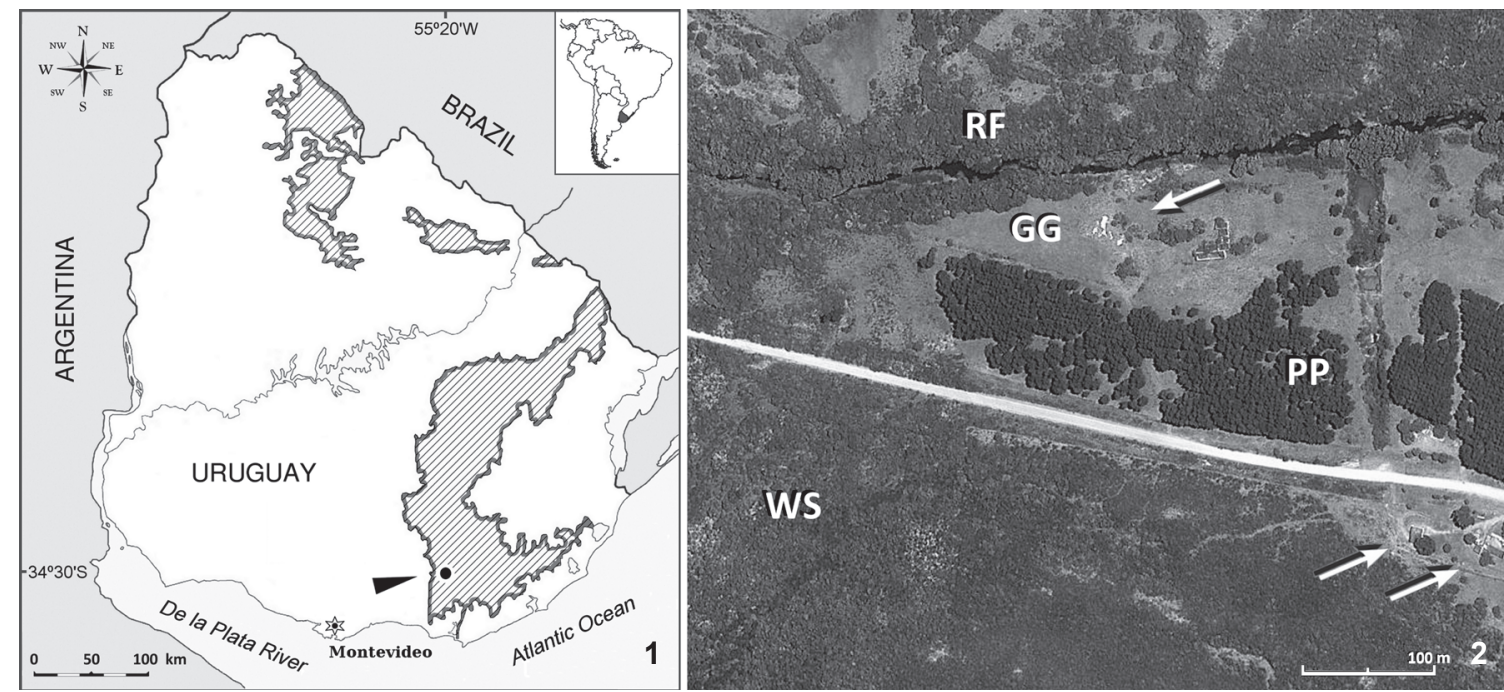

Figures 1-2. (1) Location of the study area in the Uruguayan Eastern Serranías (arrowhead). Northern and Eastern Serranías unit (forward slashes), modified from EVIA \& GUDYNAS (2000). (2) Satellite photograph (from Google Earth free virtual globe, map and geographical information program) showing part of the sampled area where coprophilous and necrophilous insects were collected. Woodlands sierra (WS), riparian forest (RF), grazing grassland (GG), and pine plantation (PP). Arrows indicate rural houses.

Sebastiania commersoniana (Baill.) L. B. Sm. \& Downs (Euphorbiaceae), Eugenia uniflora L. (Myrtaceae), and xerophilous species in the periphery such as Rapanea laetevirens Mez (Myrsinaceae), Celtis spinosa Spreng. (Cannabaceae), Schinus longifolius (Lindl.) Speg. (Anacardiaceae), and Scutia buxifolia Reissek (Rhamnaceae) (MuÑoz et al. 1993).

Pine plantation (PP). It is an artificial Pinus elliottii Englem. (Pinaceae) plantation, established in 1987 on previously natural grassland covering $1.5 \mathrm{ha}$, and is used as a refuge by cattle. It is adjacent to the grazing grassland area and is located 1-2 km away from the sierras natural areas.

Grazing grassland (GG). Narrow corridors (1.5 ha) of grasslands between the riparian forest and the pine plantation areas, managed year round to provide food for livestock. Herbs and grass species forming pastures include Axonopus P. Beauv. spp. (Panicoideae), Paspalum notatum Flüggé (Panicoideae), P. dilatatum Poir., P. plicatulum Michx., Vulpia australis (Steud.) Blom (Pooideae), and Stipa charruana Arechav. (Pooideae) (Millot et al. 1987).

Two independent replicates of each habitat, located 1 $\mathrm{km}$ apart, were surveyed monthly from May 2002 through April 2003. Coprophilous and necrophilous insects were sampled using pitfall traps baited with cow dung (from livestock fed local grasses) or cow liver, buried with the rim at ground level and filled with an aqueous solution of formaldehyde (10\%) and a drop of detergent (Figs 3-5). The bait (150 g) was placed in the middle of the upper plastic jar, which was perforated in its bottom, allowing insects to fall into a second jar containing the preserving fluid (Fig. 3). In each habitat, three pitfall traps were placed at $20 \mathrm{~m}$ intervals, resulting in a total of 288 traps.
Baited traps remained in place for a week; the captured insects were sorted in the laboratory. All dipteran insects were preserved in ethanol 70\% until identification. Drosophila samples were counted and identified to species using characters of the external morphology and, in some cases, the male and/or female terminalia, according to the method detailed by Bächlı $e t$ al. (2004). The keys and/or illustrations of Freire-Maia \& PavaN (1949), Frota-Pessoa (1954), Brncic \& Santibañez (1957), Spassky (1957), Val (1982), Vilela (1983), Vilela \& Bächli (1990), Bächli et al. (2000), and VileLA et al. (2004) were used. Male and female specimens used for species identification were doublemounted (glued to cardboard tips soon after drying, according to Bächli et al. 2004: 3), labeled and deposited as vouchers at the Museu de Zoologia, Universidade de São Paulo (Brazil), and at the collection of Sección Entomología, Departamento de Biología Animal of the Facultad de Ciencias, Universidad de la República, Montevideo (Uruguay).

Total sample estimates of species richness and abundance in each habitat were used to compute the following ecological indexes: Shannon $\left(\mathrm{H}^{\prime}=-\Sigma\right.$ pi ln pi), Berger-Parker $(\mathrm{d}=\mathrm{Nmax} / \mathrm{N})$ and Pielou evenness $\left(E=H^{\prime} / H m a x\right)$ (Magurran 1988). Pairedsample Student's t tests (ZAR 1994) were used to examine differences in species diversity between dung and carrion baited pitfall traps. A matrix was constructed using absolute abundance of samples in each habitat and each species at dung and carrion baited traps. Sample-based rarefaction curves were constructed to assess species richness for each habitat according to baited trap. The resultant curve is a plot of the number of species as a function of the number of samples, which also minimizes the effect of the absence of samples by loss of traps. Rank abun- 

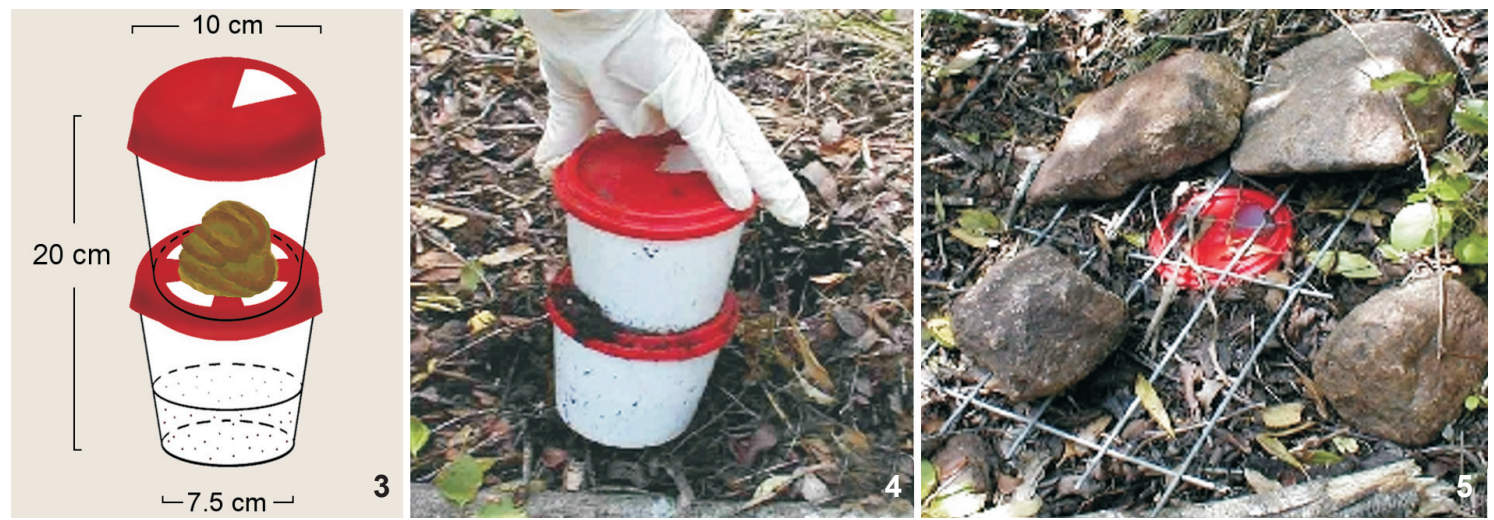

Figures 3-5. Schematic representation of the dung (or carrion) baited pitfall trap (3) used in this study containing the bait (above) and the fixative (below). The pitfall trap (4) before being buried with the rim at ground level (5).

dance analyses (Whittaker plots) were built to display the relative species abundance attracted to both dung and carrion baited trap in each habitat. The rank abundance curve provides a means for visually representing species richness and species evenness. Analysis of similarities (ANOSIM, CLARKE 1993) was performed to statistically test whether the species attracted to dung or carrion baited traps varied significantly between habitats. Analysis of Similarity Percentage (SIMPER, CLARKE 1993) was used to assess the contribution of each species to the average Bray-Curtis dissimilarity between habitats. The relationships between habitats or species composition in dung or carrion baited traps were analyzed using Morisita similarity index (KREBS 1999), followed by cluster analysis using the UPGMA method (SNEATH \& SoKaL 1973). For statistical analysis (natural logarithmic transformation in number of individuals) $\ln (\mathrm{n}+1)$ was used. All data analyses were carried out using PAST version 2.09 (HAMmER et al. 2001) and Biodiversity Pro version 2.0 (Biodiversity Pro: Free Statistics Software for Ecology).

\section{RESULTS}

In this study over 20,000 Diptera were collected at the Sierra de Minas in a twelve-month period (Tab. I). Most of them were coprophagous $(78.10 \%, \mathrm{n}=15,630)$ with a lower percentage of necrophagous $(21.90 \%, \mathrm{n}=4,382)$. Temporal and spatial variations in abundance were observed among dung and carrion traps samples. Diptera were most abundant from October to December, then again in March and April, most probably due to the total precipitation peaks recorded in those (or immediately previous) months (Fig. 6). Considering the accidental loss of some monthly samples, the spatial and temporal data on Diptera composition in each habitat should be viewed as tentative.

A total of 289 drosophilids (131 in dung traps and 158 in carrion traps), belonging to 12 species of Drosophila, were identified: eleven species in the subgenus Drosophila and one spe-

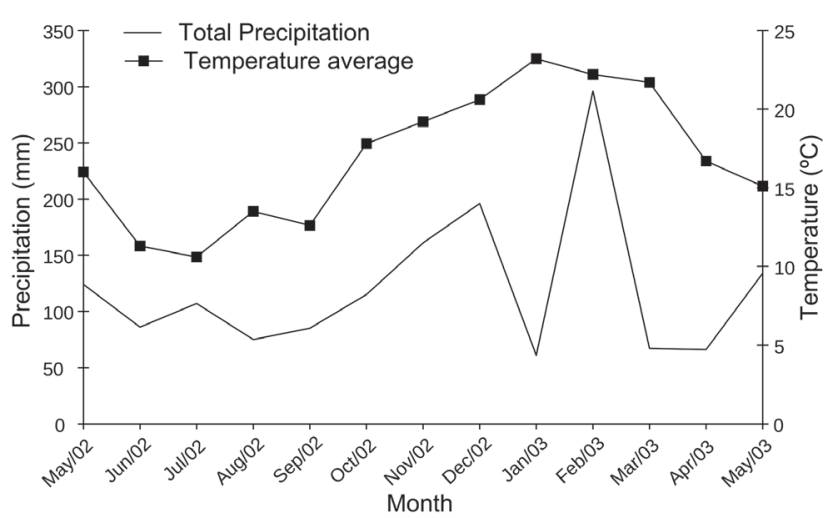

Figure 6. Temperature and rainfall monthly averages during the study period. Source: Dirección Nacional de Meteorología, Uruguay.

cies (D. willistoni Sturtevant, 1916) in the subgenus Sophophora (Tab. II). With the exception of Drosophila cardini Sturtevant, 1916 and two undescribed species of the tripunctata group, the remaining nine species had been previously recorded from Uruguay (GoÑ et al. 1997, 1998).

The rarefaction curves of Drosophila species attracted to dung and carrion traps have shown that more (unrecorded) species may occur in the study area (Figs 7-8). Drosophila richness at the woodlands sierra (WS) habitat is likely to yield nearly 14 species, whereas the steep slope of species richness observed in the other three habitats indicates that additional species are expected to occur.

The diversity indices were low in all habitats (Tab. II). Nonsignificant differences were found at the 5\% level (Student's $t$ test) regarding species diversity in relation to the bait, dung $v s$ carrion, in three out of the four analyzed habitats, WS $(\mathrm{t}=1.17$, $\mathrm{v}=229.1, \mathrm{p}=0.24), \mathrm{RP}(\mathrm{t}=-1.47, \mathrm{v}=2.8, \mathrm{p}=0.24)$, and PP $(\mathrm{t}=$ $-0.02, \mathrm{v}=8.9, \mathrm{p}=0.99)$. The abundance of species attracted to dung and carrion baited traps in each habitat are shown in Figu- 
Table I. Abundance of Diptera collected in four habitats at the Sierra de Minas, Department of Lavalleja, Uruguay, from May 2002 to April 2003.

\begin{tabular}{|c|c|c|c|c|c|c|c|c|c|c|c|c|c|}
\hline \multirow{2}{*}{ Habitat/Baited pitfall traps } & \multicolumn{8}{|c|}{2002} & \multicolumn{4}{|c|}{2003} & \multirow{2}{*}{ Total } \\
\hline & May & Jun & Jul & Aug & Sep & Oct & Nov & Dec & Jan & Feb & Mar & Apr & \\
\hline Woodlands sierra/Dung & 0 & 30 & 0 & 0 & 0 & 558 & 516 & 102 & 94 & 115 & 145 & 439 & 1999 \\
\hline Carrion & 0 & 22 & 0 & 0 & 0 & 250 & 92 & 35 & 24 & 16 & 33 & 686 & 1158 \\
\hline Riparian forest/Dung & 0 & 0 & 0 & 0 & 0 & 775 & 457 & 965 & 47 & 0 & 36 & 170 & 2450 \\
\hline Carrion & 0 & 0 & 0 & 0 & 0 & 1984 & 294 & 65 & 31 & 14 & 64 & 361 & 2813 \\
\hline Pine plantation/Dung & 0 & 0 & 0 & 0 & 0 & 473 & 732 & 6170 & 23 & 201 & 549 & 113 & 8261 \\
\hline Carrion & 0 & 0 & 0 & 0 & 0 & 5 & 46 & 11 & 14 & 0 & 28 & 120 & 224 \\
\hline Grazing grassland/Dung & 0 & 0 & 0 & 0 & 0 & 156 & 568 & 1992 & 54 & 0 & 90 & 60 & 2920 \\
\hline Carrion & 0 & 0 & 0 & 0 & 0 & 14 & 34 & 30 & 13 & 2 & 45 & 49 & 187 \\
\hline Total & 0 & 52 & 0 & 0 & 0 & 4215 & 2739 & 9370 & 300 & 348 & 990 & 1998 & 20012 \\
\hline
\end{tabular}

Table II. Species richness, abundance of Drosophila spp. and ecological indexes calculated for each habitat surveyed at the Sierra de Minas, Department of Lavalleja, Uruguay, from May 2002 to April 2003. Dung (D) and carrion (C) baited pitfall traps.

\begin{tabular}{|c|c|c|c|c|c|c|c|c|c|c|c|c|c|c|c|c|}
\hline \multirow{3}{*}{ Species group } & \multirow{3}{*}{ Species } & \multicolumn{4}{|c|}{ Woodlands sierra } & \multicolumn{4}{|c|}{ Riparian forest } & \multicolumn{4}{|c|}{ Pine plantation } & \multirow{2}{*}{\multicolumn{2}{|c|}{$\begin{array}{c}\text { Grazing } \\
\text { grassland }\end{array}$}} & \multirow{3}{*}{ Total } \\
\hline & & \multirow{2}{*}{\multicolumn{2}{|c|}{$\frac{\text { Dung }}{\text { Male Female }}$}} & \multirow{2}{*}{\multicolumn{2}{|c|}{$\frac{\text { Carrion }}{\text { Male Female }}$}} & \multirow{2}{*}{\multicolumn{2}{|c|}{$\frac{\text { Dung }}{\text { Male Female }}$}} & \multirow{2}{*}{\multicolumn{2}{|c|}{$\frac{\text { Carrion }}{\text { Male Female }}$}} & \multirow{2}{*}{\multicolumn{2}{|c|}{$\frac{\text { Dung }}{\text { Male Female }}$}} & \multirow{2}{*}{\multicolumn{2}{|c|}{$\frac{\text { Carrion }}{\text { Male Female }}$}} & & & \\
\hline & & & & & & & & & & & & & & Male & emale & \\
\hline cardini & D. cardini & 1 & 1 & 0 & 0 & 0 & 0 & 0 & 0 & 0 & 0 & 0 & 0 & 0 & 0 & 2 \\
\hline guarani & D. ornatifrons & 33 & 58 & 29 & 82 & 0 & 0 & 0 & 0 & 0 & 0 & 0 & 0 & 0 & 0 & 202 \\
\hline immigrans & D. immigrans & 0 & 1 & 0 & 6 & 0 & 0 & 2 & 11 & 1 & 0 & 0 & 0 & 0 & 0 & 21 \\
\hline mesophragmatica & D. gaucha & 0 & 0 & 1 & 1 & 0 & 0 & 1 & 5 & 2 & 7 & 0 & 1 & 0 & 0 & 18 \\
\hline \multirow[t]{4}{*}{ repleta } & D. hydei & 0 & 1 & 0 & 0 & 0 & 0 & 0 & 0 & 0 & 0 & 0 & 0 & 0 & 0 & 1 \\
\hline & D. mercatorum & 0 & 0 & 0 & 1 & 0 & 0 & 0 & 0 & 0 & 0 & 0 & 0 & 0 & 0 & 1 \\
\hline & D. meridionalis & 1 & 0 & 0 & 0 & 0 & 0 & 0 & 0 & 0 & 0 & 0 & 0 & 0 & 0 & 1 \\
\hline & D. repleta & 0 & 0 & 0 & 0 & 0 & 1 & 0 & 0 & 0 & 0 & 0 & 0 & 1 & 1 & 3 \\
\hline \multirow[t]{3}{*}{ tripunctata } & D. mediovittata & 0 & 1 & 0 & 5 & 0 & 1 & 0 & 1 & 0 & 2 & 0 & 1 & 0 & 0 & 11 \\
\hline & D. aff. nappae & 8 & 1 & 1 & 1 & 0 & 0 & 2 & 1 & 2 & 3 & 1 & 1 & 0 & 0 & 21 \\
\hline & D. aff. paraguayensis & 1 & 1 & 0 & 0 & 0 & 0 & 0 & 0 & 0 & 0 & 0 & 0 & 0 & 0 & 2 \\
\hline willistoni & D. willistoni & 1 & 3 & 1 & 0 & 0 & 0 & 0 & 0 & 0 & 0 & 0 & 1 & 0 & 0 & 6 \\
\hline \multicolumn{2}{|l|}{ Total } & 45 & 67 & 32 & 96 & 0 & 2 & 5 & 18 & 5 & 12 & 1 & 4 & 1 & 1 & 289 \\
\hline \multicolumn{2}{|l|}{ Abundance } & \multicolumn{2}{|c|}{112} & \multicolumn{2}{|c|}{128} & \multicolumn{2}{|c|}{2} & \multicolumn{2}{|c|}{23} & \multicolumn{2}{|c|}{17} & \multicolumn{2}{|c|}{5} & \multicolumn{2}{|c|}{2} & \\
\hline \multicolumn{2}{|l|}{ Richness } & \multicolumn{2}{|c|}{9} & \multicolumn{2}{|c|}{7} & \multicolumn{2}{|c|}{2} & \multicolumn{2}{|c|}{4} & \multicolumn{2}{|c|}{4} & & & & & \\
\hline Diversity (Shannon & -Wiener, $\mathrm{H}^{\prime}$ ) & & 80 & & 60 & & & & 08 & & 12 & & & & & \\
\hline Dominance (Berge & r-Parker, d) & & 81 & & 87 & & & & 57 & & 53 & & & & & \\
\hline Evenness (Shannor & , E) & & 37 & & 81 & & & & 78 & & 80 & & & & & \\
\hline
\end{tabular}

res 9-11. The GG habitat was excluded from this figure because only a few samples were collected in it, all of which from carrion baited traps (Tab. II). The WS habitat contributed between $75 \%$ and $58 \%$ of the observed species richness registered in dung and carrion baited traps, respectively (Tab. II). By contrast, there is a sharp fall in the species abundance curves for the RP and PP habitats. These habitats, surrounded by open fields, contributed with relatively moderate species richness, between $17 \%$ to $33 \%$ in RP (dung and carrion baited traps, respectively), and 33\% in PP habitats (Tab. II). One species, D. ornatifrons Duda, 1927, was the most abundant species in WS habitat and accounted for $83 \%$ and almost $87 \%$ of the individuals attracted to dung and carrion baited traps, respectively (Figs 9-11). This endemic species was restricted to the WS habitat. Other species, D. gaucha Jaeger 

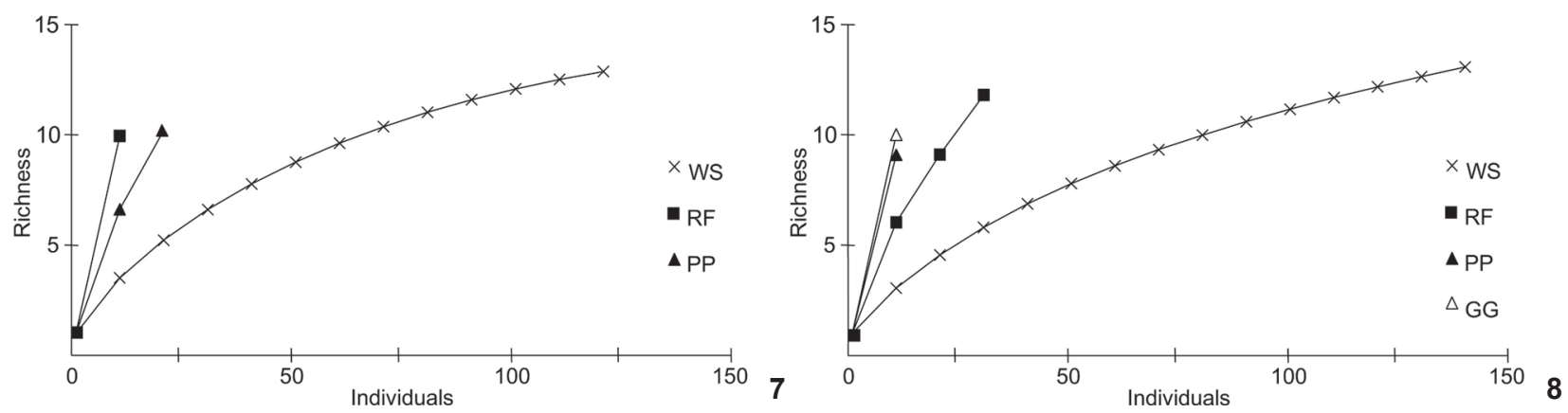

Figures 7-8. Rarefaction curves of species richness estimates of Drosophila recorded for each habitat, in (7) dung and (8) carrion baited traps. Woodlands sierra (WS), riparian forest (RF), pine plantation (PP), and grazing grassland (GG).

\& Salzano, 1953, D. immigrans Sturtevant, 1921, D. aff. nappae Vilela, Valente \& Basso-da-Silva, 2004 have a slighter wider distribution in all habitats surveyed at the Sierra de Minas, except the GG habitat (Figs 9-11). The GG habitat, modified by livestock management, showed the lowest species richness and absolute abundance, with only one species, D. repleta Wollaston, 1858 , recorded in carrion baited traps.

Different habitats supported particular coprophilous and necrophilous Drosophila species as shown by the ANOSIM analyses (Global $\mathrm{R}=0.09, \mathrm{p}=0.008$ for the dung baited trap group, and $\mathrm{R}=0.04, \mathrm{p}=0.04$ for the carrion-baited trap group, respectively). As expected, significant differences in species composition were found within some pairwise comparisons of Drosophila species (Tab. III). The SIMPER analysis pointed to D. ornatifrons as the taxon primarily responsible for the observed differences between some groups of samples. In dung baited traps, this species contributed with $35.01 \%$ and $33.74 \%$ of the observed differences between WS and RF, and between WS and PP habitats, respectively (the overall dissimilarity was $65.07 \%$ and $64.36 \%$, respectively). In carrion baited traps, D. ornatifrons contributed with $30.11 \%$ between WS and RF habitats (showing an overall dissimilarity of $54 \%$ ).

Table III. ANOSIM. Pairwise comparison of Drosophila species abundance and composition between habitats for dung (D) and carrion (C) baited pitfall traps.

\begin{tabular}{ccccccc}
\hline \multirow{2}{*}{ Groups } & \multicolumn{2}{c}{ Dung } & & \multicolumn{2}{c}{ Carrion } \\
\cline { 2 - 3 } \cline { 5 - 6 } \cline { 5 - 6 } & R statistics & $\mathrm{p}(\%)$ & & R statistics & $\mathrm{p}(\%)$ \\
\hline WS vs. RF & 0.170 & $1.12^{*}$ & & 0.040 & 18.36 \\
WS vs. PP & 0.161 & $1.24^{*}$ & & 0.070 & 8.54 \\
WS vs. GG & - & - & & 0.134 & $1.56^{*}$ \\
RF vs. PP & -0.020 & 100.00 & & -0.011 & 56.01 \\
RF vs. GG & - & - & & 0.030 & 9.42 \\
PP vs. GG & - & - & & 0.002 & 58.09 \\
\hline
\end{tabular}

WS = Woodlands sierra, RF = Riparian forest, $\mathrm{PP}=$ Pine plantation, and $\mathrm{GG}=$ Grazing grassland. ${ }^{*} \mathrm{p}<5 \%$.
Cluster analysis using habitats association (Figs 12 and 13) showed that WS, RF and PP were associated in dung and carrion traps, with low and medium similarity values, respectively. In carrion traps (Fig. 13), GG habitat was unassociated, probably due to the low abundance and species richness, with no samples in dung traps (Tab. II). Different associations of species were obtained in dung and carrion traps (Figs 14 and 15). In dung traps (Fig. 14), two clusters of species showed the highest level of association: one formed by six species (D. cardini, D. hydei, D. ornatifrons, D. meridionalis Wasserman, 1962, D. aff. paraguayensis Duda, 1927, and D. willistoni) and the other by two members (D. immigrans and $D$. aff. nappae). They were associated to other Drosophila species at varying levels of similarity (values above 0.4). In carrion traps (Fig. 15), seven out of eight species were associated to each other at varying levels of similarity. In both types of traps, D. repleta was unassociated and divergent from the other species.

\section{DISCUSSION}

Drosophila ornatifrons had been previously registered in a

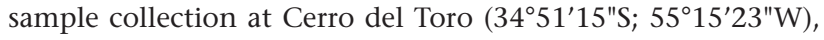
an isolated topographic accident of Sierra de las Animas, located at the southernmost region in the Eastern Serranías System, using conventional banana-baited traps (GoÑ et al. 1998). Drosophila ornatifrons (also cited under its junior synonym, D. guarani Dobzhansky \& Pavan, 1943) was formerly believed to be endemic to the Atlantic Forest biome of Brazil (SENE et al. 1980). However, later on, it was collected in gallery forests, xerophitic enclaves, highland rocky fields and other transitional areas between the Atlantic Forest and adjacent biomes (Araújo \& VALENTE 1981, Tidon-Sklorz et al. 1994, Vilela \& Mori 1997, Mateus et al. 2006, Tidon 2006). It was also recorded from Colombia, Bolivia and Ecuador (RAFAel \& Vela 2000). Temporal and spatial studies of drosophilids in the cerrado biome indicate that $D$. ornatifrons has been more frequently found in gallery forests than in the savanna-like vegetation (or cerrado), and has low but significant positive correlation with monthly humidity and light in 

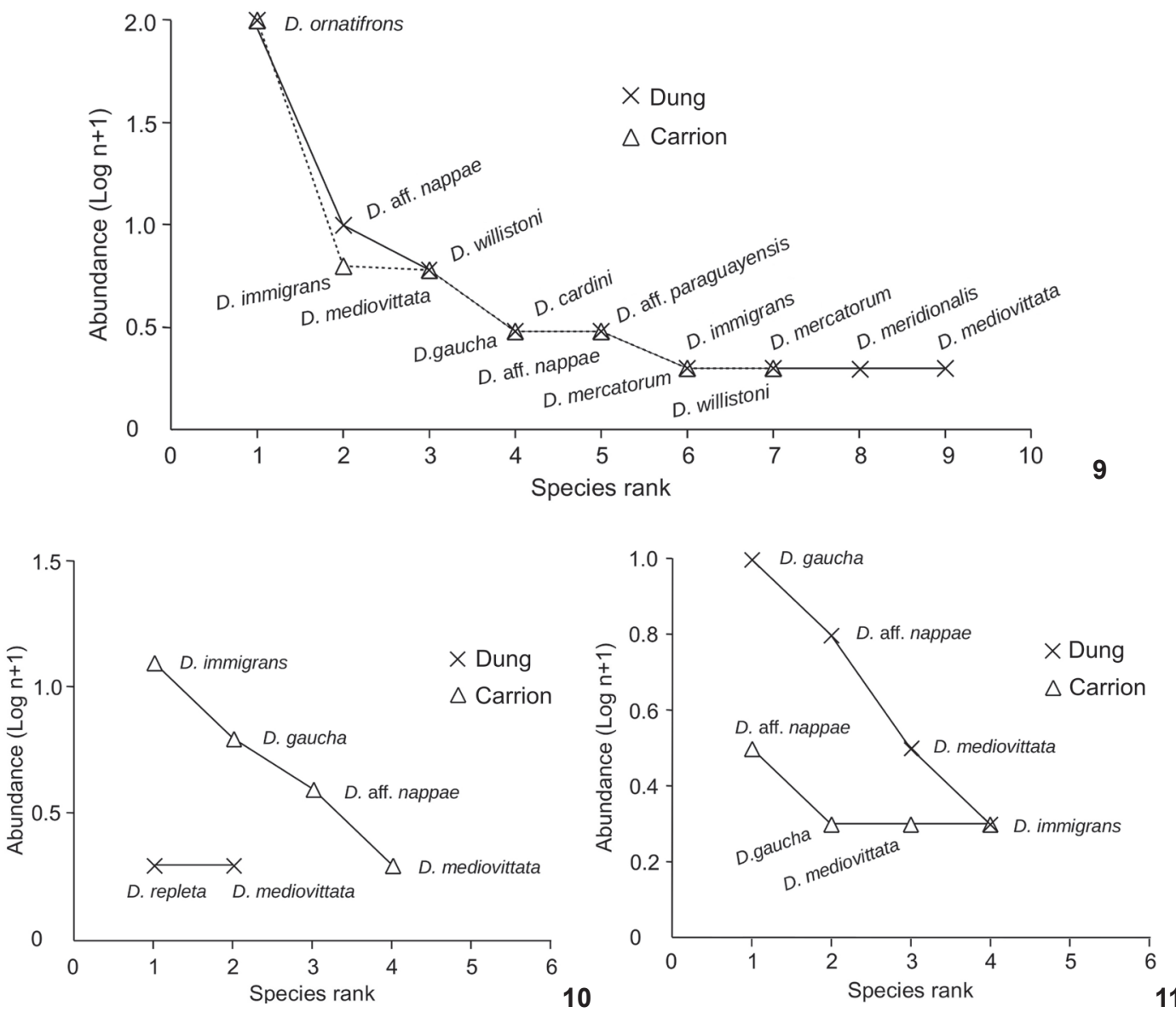

Figures 9-11. Rank-abundance curves of Drosophila species attracted to dung or carrion baited traps in each habitat sampled, woodlands sierra (9), riparian forest (10), and pine plantation (11). Grazing grasslands were intentionally omitted.

one of the two sites surveyed, close to the city of Brasília (Tidon 2006). Fly collecting in the Paranã Valley, located in the cerrado biome, revealed that the few collected samples of $D$. ornatifrons were associated with the wet season (MATA et al. 2008). There are few records on the breeding sites of this species. ARAújo \& VALENTE (1981) mentioned fallen fruits of seven species belonging to different plant families, Schefflera morototoni (Aublet) Maguire et al (Araliaceae), Bromelia balansae Mez (Bromeliaceae), Euphorbia phosphorea Mart. (Euphorbiaceae), Strychnus brasiliensis (Spreng.) Mart. (Loganiaceae), Inga sp. (Mimosaceae), Prunus subcoriacea (Chodat \& Hassl.) Koehne (Rosaceae), and Randia armata (Sw.) (Rubiaceae) in Parque do Turvo (RS, Brazil), whereas Roque et al. (2009) registered only one specimen of $D$. ornatifrons among 4,163 drosophilids emerged from fallen fruits of Emmotum nitens (Benth.) Miers (Icacinaceae) in the Brazilian savanna.

Two species of the tripunctata species group, D. mediovittata and $D$. aff. nappae, were not very abundant among the Drosophila samples collected both in dung and carrion traps. Drosophila mediovittata belongs to the subgroup IV (Frota-PESSOA 1954) and seems to be endemic to Brazil and Uruguay. In Uruguay, this species breeds on a limited number of substrates such as flowers of Erythrina crista-galli L. (Fabaceae) and on rotting cladodes of Opuntia arechavaletai Speg. (Cactaceae) collected from the Atlantic wetlands in the Department of Rocha (GoÑ et al. 1998).

Drosophila immigrans is a cosmopolitan species that had been previously collected in several localities in Uruguay (GoÑI et al. 1997, 1998).

Drosophila gaucha is the only member of the mesophragmatica species group that seems to be widely distributed outside the Andean region. It is found in Ecuador, Bolivia, Argentina, Brazil, and Uruguay (JAEger \& SALZANo 1953, BRNCIC \& Santibañez 1957, Brncic et al. 1971, GoÑi et al. 1997, Rafael \& Vela 2000). According to Brncic \& Santibañez (1957) there are no morphological differences between $D$. gaucha and its sibling species, D. pavani Brncic, 1957. Since the latter species has never been collected in the southernmost Brazilian state of Rio Grande do Sul, which includes the type locality of the former and extends contiguously to Uruguay, the specimens collected 


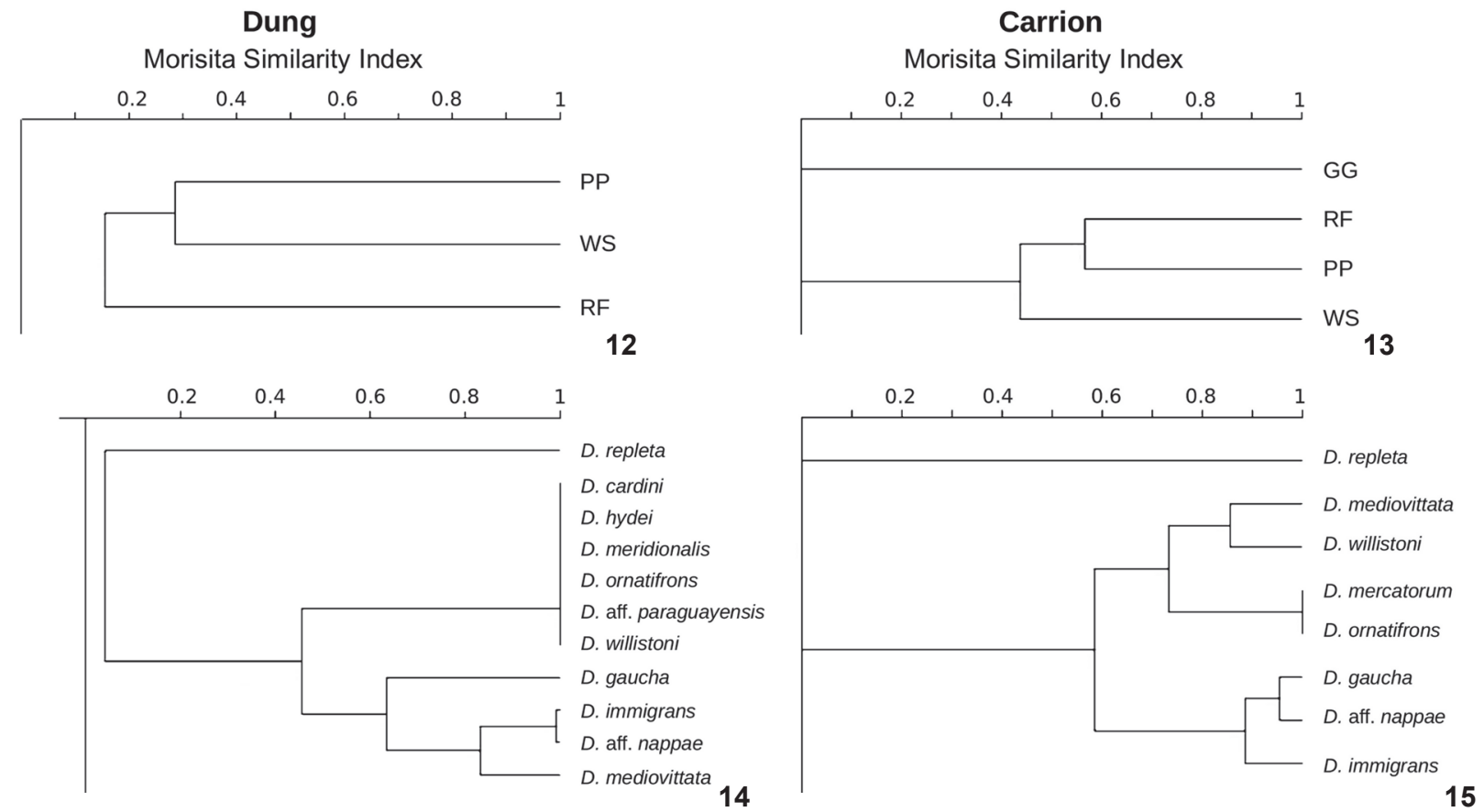

Figures 12-15. UPGMA dendrograms with Morisita's similarity index representing habitat (upper, 12 and 13) and Drosophila species association (lower, 14 and 15) attracted to dung and carrion baited pitfall traps.

were tentatively identified as belonging to D. gaucha.

Three species of the repleta species group, D. hydei Sturtevant, 1921, D. mercatorum Patterson \& Wheeler, 1942, and D. repleta were identified in our samples. Drosophila hydei and $D$. repleta are cosmopolitan species, whereas D. mercatorum is semicosmopolitan. In previous collections by GoÑ et al. $(1997,1998)$, D. hydei was frequently found associated with pristine as well as man-modified environments. In the present study, only one female specimen of $D$. hydei was sampled at the WS habitat (Tab. II). Drosophila repleta is a domestic species, often found in restaurants, urinals and inside houses, especially kitchens (STURTEVANT 1918, CоE 1943), as well as in poultry manure, from which Вісно et al. (2004) identified 9,229 adults of this species among 28,720 Diptera collected, representing $32 \%$ of the flies. As just one female imago of $D$. repleta was collected in dung baited traps placed at the RF habitat, it seems that this species is not as attracted to cow dung baits, containing only feces, as it is to the semisolid mixture of feces and of uric acid of the poultry manure. Whether the uric acid is responsible for the strong attraction that poultry manure and restaurant's urinals exert on flies (COE 1943) remains an open question. Although $D$. repleta was absent from necrophagous insect communities sampled during the decomposition of medium-sized domestic pig carcasses at a central European urban habitat (GRASSBERger \& Frank 2004), in the present survey one male and one female of this species were collected in carrion baited pitfall traps in the GG habitat (Tab. II). The occurrence of $D$. repleta in the latter traps may indicate the presence of human settlements near the sampled areas (Fig. 2). Just one female of $D$. mercatorum, probably belonging to D. mercatorum pararepleta, was collected in the present study, in a carrion baited trap set at the WS habitat (Tab. II).

Finally, a few specimens of $D$. cardini were collected in dung traps at the most preserved habitat, the WS. This species has been found in Florida (USA), Mexico, Central and South America, and the West Indies, and later recorded from the Hawaiian Islands (HERFORTH et al. 1984), where it became one member of the established immigrant drosophilid species (LeBLanc et al. 2009). In Brazil, this species has been collected in semi-arid areas such as caatingas, but can also be found in cerrados (savannas), the coast and the restingas (sand dune vegetation) (VILELA et al. 2002).

This is the first inventory of Drosophila species in Sierra de Minas using pitfall traps placed across heterogeneous natural areas within a relatively small geographic area (altitude of sampled sites varied between $110-230 \mathrm{~m}$, and the longest distance between these sites was about $5 \mathrm{~km}$ ). Endemic and cosmopolitan species were collected in almost all habitats. Among the endemic species, one previously unrecorded species from Uruguay, $D$. cardini, and two undescribed ones of the tripunctata group were registered. However, some widespread cosmopolitan generalists, such as D. simulans Sturtevant, 1919, which is frequently collected in natural areas of Uruguay (GoÑ et al. 1998), was absent from our traps. This observation indicates that the use of pitfall traps to collect Drosophila might result in an underestimation of the true species richness. This hypothesis is consistent with the 
(higher) expected richness estimated in this study for the sampled area. The abundance and richness of endemic species (D. cardini, $D$. ornatifrons, $D$. meridionalis, $D$. aff. nappae, $D$. aff. paraguayensis and $D$. willistoni) are associated with habitat differences. We infer this based on the fact that statistical differences, as well as low habitat association (estimated in dung and carrion baited traps), were observed among the Drosophila assemblages of the sampled areas. At the most preserved area, the WS habitat, most of the species are at least partially (or totally) dependent on the forest environment, where the greatest number of species were sampled by both dung and carrion baited traps. Furthermore, in this habitat, D. ornatifrons was dominant with a restricted distribution, suggesting its association with local resource(s) availability and/or particular forest environmental conditions. On the other hand, in the natural modified habitat where anthropogenic disturbance was present, the abundance and richness of Drosophila shifted to low indices, as observed in the GG habitat, with only one species, $D$. repleta, recorded in carrion baited traps.

The results presented here indicate that carrion and dung baited pitfall traps, though not efficient in terms of expected richness, it can be exploited as an additional and reliable sampling method. However, it does not replace the more conventional traps (based only on banana or bakers' yeast-fermented banana bait) used to study Drosophila biodiversity and ecology. Comparative studies involving insect collections using different baits (fruits, carrion, and dung), conducted simultaneously, can be employed to test the usefulness of alternative baits for understanding more fully the dynamics of frequency and abundance of drosophilid species in natural environments. Our findings support the view that the Drosophila assemblage attracted to carrion and dung baited pitfall traps is quite sensitive to natural forest or natural grasslands, and can be used to monitor environmental disturbance in conservation programs along with other necrophilous and coprophilous insects.

\section{ACKNOWLEDGEMENTS}

The authors are grateful to Walter Norbis (FREP, Facultad de Ciencias, Universidad de la República, UdelaR, Uruguay) for his advice on ecological and statistical analysis of the data; to Virginia Fernandez and Fernando Pesce (Geografía, Facultad de Ciencias, UdelaR) for their suggestions on the geographic profile of Uruguay, and two anonymous reviewers for their valuable suggestions. We thank Fernando Luces for the English correction, and PEDECIBA (Programa de Desarrollo de Ciencias Básicas) for providing financial support for the fieldwork to PG-V, and CSIC (UdelaR) for supporting a visit of BG to Brazil.

\section{LITERATURE CITED}

Araújo, A.M. \& V.L.S. Valente. 1981. Observações sobre alguns Lepidópteros e Drosofilídeos do Parque to Turvo, RS. Ciência e Cultura 33 (11): 1485-1490.
Bächli., G.; C.R. Vilela \& V. Ratcov. 2000. Morphological differences among Drosophila paraguayensis Duda, 1927 and its close relatives (Diptera, Drosophilidae). Bulletin de la Société Entomologique Suisse 73: 67-92.

Bächli, G.; C.R. Vilela; S.A. Escher \& A. Saura. 2004. The Drosophilidae (Diptera) of Fennoscandia and Denmark. Leiden, Brill, 362p.

Bicho, C. De L.; L.M. De Almeida; P.B. Ribeiro \& P. Silveira Júnior. 2004. Flutuação de Diptera em granja avícola, Pelotas, Rio Grande do Sul. Brasil. Iheringia, Série Zoologia, 94 (2): 205-210.

Brazeiro, A.; M. Achkar; A. Canavero; C. Fagúndez; E. González; I. Grela; F. Lezama; R. Maneyro; L. Berthesaghi; A. Camargo; S. Carreira; B. Costa; D. Nuñez; I. da Rosa \& C. Toranza. 2008. Prioridades geográficas para la conservación de la biodiversidad terrestre de Uruguay. Resumen Ejecutivo Proyecto PDT 32-26. 46p. Montevideo. Available online at: http://www.universidadur.edu.uy/retema/grupos.html\#ar. [Accessed: 13.VI.2011]

BRncic, D. \& S.K. SANTibañez. 1957. The mesophragmatica group of species of Drosophila. Evolution 11 (3): 300-310.

Brncic, D.; P.S. Nair \& M.R. Wheeler. 1971. Cytotaxonomic relationships within the mesophragmatica species group of Drosophila. The University of Texas Publication 7103: 1-16.

Clarke, K.R. 1993. Non-parametric multivariate analysis of changes in community structure. Australian Journal of Ecology 18: 117-143.

CoE, R.L. 1943. Drosophila repleta Wollaston (Dipt., Drosophilidae) new to Britain, with notes on the species and some account of its breeding-habits. Entomologist's Monthly Magazine 79: 204-206.

Deloya, C.; G. Ruiz-Lizarraga \& M.A. Morón. 1987. Análisis de la entomofauna necrófila en la región de Jojutla, Morelos, México. Folia Entomológica Mexicana 73: 157-171.

EviA, G. \& E. Gudynas. 2000. Ecología del Paisaje en Uruguay. Aportes para la conservación de la Diversidad Biológica. Sevilla, MVOTMA, AECI y Junta de Andalucía, 173p.

Freire-Maia, N. \& C. Pavan. 1949. Introdução ao estudo da Drosófila. Cultus 1 (5): 1-71.

Frota-PessoA, O. 1954. Revision of the tripunctata group of Drosophila with description of fifteen new species (Drosophilidae, Diptera). Arquivos do Museu Paranaense 10: 253-304.

GonzÁlez-Vainer, P. \& E. Morelli. 2008. Relevamiento de los coleópteros coprófilos y necrófilos de Sierra de Minas, Uruguay (Insecta: Coleoptera). Boletín de la Sociedad Zoológica del Uruguay 17: 20-33.

Goñi, B.; M.E. Martinez \& P. Daguer. 1997. Studies of two Drosophila (Diptera, Drosophilidae) communities from urban Montevideo, Uruguay. Revista Brasileira de Entomologia 41 (1): 89-93.

Goñi, B.; M.E. Martinez; V.L.S. Valente \& C.R. Vilela. 1998. Preliminary data on the Drosophila species (Diptera, Drosophilidae) from Uruguay. Revista Brasileira de Entomologia 42 (3/4): 131-140.

Grassberger, M. \& C. Frank. 2004. Initial study of arthropod succession on pig carrion in a central European urban 
habitat. Journal of Medical Entomology 41 (3): 511-523. Hammer, Ø.; D.A.T. HARPer \& P.D. Ryan. 2001. PAST: Paleontological Statistics Software Package for Education and Data Analysis. Palaeontologia Electronica 4 (1) art. 4: 9p. Available online at: http://palaeo-electronica.org/2001_1/past/issue1_01.htm [Accessed: 13.VI.2011].

Herforth, R.S.; H.L. Carson \& L. Chang. 1984. A new arrival to the Hawaiian Islands: Drosophila cardini. Drosophila Information Service 60: 124.

JAEGER, C.P. \& F.M. SALZANO. 1953. "Drosophila gaucha”, a new species from Brasil. Revista Brasileira de Biologia 13 (3): 205-207.

Krebs, J.C. 1999. Ecological Methodology. Menlo Park, Addison-Welsey Educational Publishers, $2^{\text {nd }}$ ed., 620p.

Leblanc, L.; P.M. O'Grady; D. Rubinoff \& S.L. Montgomery. 2009. New Immigrant Drosophilidae in Hawaii, and a Checklist of the Established Immigrant Species. Proceedings of the Hawaiian Entomological Society 41: 121-127.

MagurRan, A.E. 1988. Ecological diversity and its measurement. New Jersey, Princeton University Press, 179p.

Mata, R.A. DA; F. Roque \& R. Tidon. 2008. Drosophilids (Insecta, Diptera) of the Paranã valley: eight new records for the Cerrado biome. Biota Neotropica 8 (1): 55-60.

Mateus, R.P.; M.L. Buschini \& F.M. Sene. 2006. The Drosophila community in xerophytic vegetations of the upper ParanáParaguay river basin. Brazilian Journal of Biology 66 (2B): 719-729. doi: 10.1590/S1519-69842006000400016.

Millot, J.; D. Risso \& R. Methol.1987. Relevamiento de pasturas naturales y mejoramientos extensivos en áreas ganaderas del Uruguay. Montevideo, MGAP, Informe Técnico para la Comisión Honoraria del Plan Agropecuario, FUCREA, 195p.

Morón, M.A. \& J.A. López-Méndez. 1985. Análisis de la entomofauna necrófila de un cafetal en el Soconusco, Chiápas, México. Folia Entomológica Mexicana 63: 47-59.

Morón, M.A. \& R. TERRÓN. 1982. Análisis de la entomofauna necrófila de la cañada de Otongo, Hidalgo. Folia Entomológica Mexicana 53: 38-39.

Morón, M.A. \& R. Terrón. 1984. Distribución altitudinal y estacional de los insectos necrófilos en la Sierra Norte de Hidalgo, México. Acta Zoológica Mexicana, n.s., 3: 1-47.

Morón, M.A.; J.F. Camal \& O. Canul. 1986. Análisis de la entomofauna necrófila del área norte de la Reserva de la Biósfera "Sian Ka'an", Quintana Roo, México. Folia Entomológica Mexicana 69: 83-98.

MuÑoz, J.; P. Ross \& P. CRAcCo. 1993. Flora indígena del Uruguay. Montevideo, Editorial Agropecuaria Hemisferio Sur, 284p.

Rafael, V. \& D. Vela. 2000. Drosophila distribution in Ecuador. Drosophila Information Service 83: 85-88.

Remedios, M.; M. Martínez \& P. González-Vainer. 2012. Estudio preliminar de los dípteros asociados a cebos de estiércol y carroña en un bosque serrano de Sierra de Minas, Uruguay. Acta Zoológica Mexicana, n.s., 28 (2): 378-390.

Roque, F.; J.D.V. Hay \& R. Tidon. 2009. Breeding sites of drosophilids (Diptera) in the Brazilian Savanna. I. Fallen fruits of Emmotum nitens (Icacinaceae), Hancornia speciosa (Apocynaceae) and Anacardium humile (Anacardiaceae). Revista Brasileira de Entomologia 53 (2): 308-313.

Sánchez-Ramos, G.; J. Lobo; M. Lara Villalón \& P. Reyes-Castillo. 1993. Distribución altitudinal y estacional de la entomofauna necrófila en la Reserva de la Biosfera "El Cielo", Tamaulipas, México. Biotam 5 (1): 13-24.

Sene, F.M.; F.C. do Val; C.R. Vilela \& M.A.Q.R. Pereira. 1980. Preliminary data on the geographical distribution of Drosophila species within morphoclimatic domains of Brazil. Papéis Avulsos de Zoologia 33 (22): 315-326.

Sneath, P.H. \& R.R. SoKal. 1973. Numerical taxonomy. The principles and practice of numerical classification. San Francisco, Freeman \& Co., XV+573p.

SPASSKY, B. 1957. Morphological differences between sibling species of Drosophila. University of Texas Publications 5721: 48-61.

Sturtevant, A.H. 1918. Flies of the genus Drosophila as possible disease carriers. Journal of Parasitology 5 (2): 84-85.

Tidon, R. 2006. Relationships between drosophilids (Diptera, Drosophilidae) and the environment in two contrasting tropical vegetations. Biological Journal of the Linnean Society 87: 233-248.

Tidon-Sklorz, R.; C.R. Vilela; F.M. Sene \& M.A.Q.R. Pereira. 1994. The genus Drosophila (Diptera, Drosophilidae) in the Serra do Cipó, state of Minas Gerais, Brazil. Revista Brasileira de Entomologia 38 (3/4): 627-637.

VAL, F.C. Do. 1982. The male genitalia of some Neotropical Drosophila: notes and illustrations. Papéis Avulsos de Zoologia 34 (27): 309-347.

Vilela, C.R. 1983. A revision of the Drosophila repleta species group (Diptera, Drosophilidae). Revista Brasileira de Entomologia 27 (1): 1-112.

VILELA, C.R. \& G. BÄCHLI. 1990. Taxonomic studies on neotropical species of seven genera of Drosophilidae (Diptera). Bulletin de la Société Entomologique Suisse 63 (Suppl.): 1-332.

Vilela, C.R. \& L. Mori. 1997. The genus Drosophila (Diptera, Drosophilidae) in the Serra do Cipó: further notes. Revista Brasileira de Entomologia 43 (3/4): 319-328.

VILELA, C.R.; A.F. G. DA Silva \& F.M. Sene. 2002. Preliminary data on the geographical distribution of Drosophila species within morphoclimatic domains of Brazil. III. The cardini group. Revista Brasileira de Entomologia 46 (2): 139-148.

Vilela, C.R.; V.L.S. Valente \& L. Basso-Da-Silva. 2004. Drosophila angustibucca Duda sensu Frota-Pessoa is an undescribed species (Diptera, Drosophilidae). Revista Brasileira de Entomologia 28 (2): 233-238. doi: 10.1590/S008556262004000200012

ZAR, J. 1994. Biostatistical analysis. New York, Prentice Hall, 718p.

Submitted: 13.I.2012; Accepted: 06.VII.2012. Editorial responsibility: Gabriel L.F. Mejdalani 